\title{
Surveying the impact of satisfaction and e-reliability on customers' loyalty in e-purchase process: a case in Pars Khodro co
}

\author{
Vahid Qaemi*
}

Department Acoounting \& Management of Payam Noor University of Damavand, Tehran, Iran

\begin{tabular}{|c|c|}
\hline A R T I C L E I N F O & A B S T R A C T \\
\hline $\begin{array}{l}\text { Article history: } \\
\text { Received May 1, } 2012 \\
\text { Accepted } 8 \text { June } 2012 \\
\text { Available online } \\
\text { June } 102012 \\
\text { Keywords: } \\
\text { E-satisfaction } \\
\text { E-confidence } \\
\text { E-loyalty } \\
\text { E-purchase process }\end{array}$ & $\begin{array}{l}\text { Today, customer return issue in e-purchase process is considered as important topic in } \\
\text { companies' marketing and managerial decision making. In this paper, we present an empirical } \\
\text { study on measuring the impact of e-loyalty for an Iranian auto-industry called Pars Khodro co. } \\
\text { The proposed study measures reliability, responsiveness, design, security/privacy as } \\
\text { independent variables, e-confidence and e-satisfaction as mediator variable, and e-loyalty as } \\
\text { dependent variable. The preliminary results show that effectiveness of e-satisfaction and e- } \\
\text { confidence on loyalty and effectiveness of e-confidence on e-satisfaction are in high level. } \\
\text { Reliability/Fulfillment and security variables on e-confidence have significant impacts, and } \\
\text { effectiveness level of reliability/Fulfillment and responsiveness and website design on e- } \\
\text { satisfaction is high. The results indicate that there is no significant relationship between } \\
\text { responsiveness and e-confidence. }\end{array}$ \\
\hline
\end{tabular}

(c) 2012 Growing Science Ltd. All rights reserved.

\section{Introduction}

During the past few years, information technology (IT) has played essential role on reaching marketing objectives and internet has become the most effective tool for communication (Chaffey et al., 2000). To find good niche in existing competitive marketing and maintaining the market, businesses need to use different techniques for customer retention. There are two ways to create a competitive advantage, which are to present cheap products and services and maintain customer loyalty (Porter, 1980). E-loyal customer normally increases profitability through long-term commitment and decreases the cost of absorbing new customers (Reichheld et al., 2000, 495). E-loyal customers are not looking for the lowest prices, but they are looking for more valuables prices. They attempt to flow new customer to shop, and hereby, provide potential rich resources of profit. In addition, e-loyal customers purchase more than new customers do, and they can receive services through lower functional costs (van Riel et al., 2001). Therefore, even if the cost of creating loyalty is more than the cost of physical shops, providing relationship and benefit growth is more important (Reichheld \& Schefter, 2000). In creating e-loyalty, several factor such as e-satisfaction (Anderson \& Srinivasan, 2003) and e-confidence (Reichheld \& Schefter, 2000) play essential roles. On the other hand, academics scholars (Slater, 1997; Woodruff, 1983), and

* Corresponding author. Tel.: +989123200031

E-mail addresses: vahid_whiite@yahoo.com (V. Qaemi) 
consultants (Gale, 1994; Laitmaki \& Kordupleski, 1997) suggested that companies should direct their strategy for customer's retention towards value creation. What brings about to customer return, is loyalty sense raised from better service represent by a company than its rivals (Hoffman et al., 1998); because, it is important to identify and to determine effectiveness level of these factors to enhance efficiency of internet sales to reach the desirable objectives. The primary objective of this paper is to identify and to analyze effective factors on customer's loyalty and satisfaction of internet purchase in Pars Khodro, and to represent options for improvement.

Duo to fast growth of e-commerce, companies try to create competitive advantages used of e-trade in their transactions with customers. Customers' returns play critical roles in companies' success, because loyal customers purchase more than others do. They also have more motivation for looking for information, stronger against advertising, and possibly a product advertising by them is more (Dick \& Basu, 1994; Rust et al., 1995, 200). Service providing cost is less for such customers (Ganesh et al., 2000; Hwang et al., 2004) because replacing new customer with existing cost more (Bhattacharya, 1998; Colgate \& Danaher, 2000, 379) but the problem is whether these customers satisfy from company's service and how we can improve their satisfaction.

Nevertheless, Pars Khodro's planning of internet sales from 5 to 10 percent of total sales has not been achieved during the past few years and this paper attempts to identify and to analyze the main influenced factors on loyalty, satisfaction, and as a result, customer return to purchase.

Regard to mention-above introduction, research questions are to determine effective factors influencing on e-loyalty on internet-purchase and how they can improve relationships between effective variants on e-loyalty. The primary goal of this survey is to increase return rate, loyalty, confidence, and customer satisfaction and as a result.

\section{Literature review}

\subsection{E-loyalty}

Loyalty is to cover all customers' needs and to continue the level of coverage (Hill \& Alexander, 2000). Loyalty can be also described as a kind of purchase repeat behavior, which reflexes intelligent decision making for purchase continuity of a brand (Bloemer \& Ruyter, 1998). Customer loyalty is the most excellent level of customer satisfaction (Hill, \& Alexander, 2000). Customer satisfaction and service quality have been defined by marketing researchers in different ways (Yazdanpanah \& Gazor, 2012), in detecting success factors of electronic customer relationship management (ECRM) system. According to Yazdanpanah and Gazor (2012), the ECRM can increase customer satisfaction and improve services. Therefore, many organizations extremely consider service quality to obtain their customers' satisfaction and loyalty (Gazor et al., 2012, Nemati et al., 2012). Totally, e-loyalty is a customer's positive and desired view to an e-business, which leads to repurchase behavior (Kim et al., 2009).

\subsection{E-confidence}

Confidence is a multidimensional social concept, which depends on environmental and composes of behavioral intents (Gefen \& Straub, 2004). Confidence is a control mechanism, which enables employees for useful contribution together with new organizational structures (Mire et al., 1995). Trust is a critical antecedent of building relationships between buyer and seller (Sirdeshmukh et al., 2002; Verhoef et al., 2002). In e-purchases, people who are more confident more likely to do internet purchase and as a result, their loyalty increase (Reichheld \& Schefter, 2000). In addition, econfidence has a direct and positive impact on e-loyalty (Sirdeshmukh et al., 2002; Verhoef et al., 2002). Based on these discussions, we build the following hypothesis,

H1: e-confidence has a positive impact on e-loyalty in Pars Khodro CO. 
H2: e-confidence has a positive impact on e-satisfaction in Pars Khodro CO.

\subsection{E-satisfaction}

E-satisfaction is defined as a collective factor, which is based on sum of satisfaction on purchase and experience of product or service (Anderson, 1995). E-satisfaction is a level of customer satisfaction from website design, web information or content, convenience of purchase, and security of purchase (Oliver, 1989). E-satisfaction has been defined as the perception of pleasurable fulfillment in the customers' transaction experiences through a commercial e-enterprise (Taylor, 1995). E-satisfaction is level of customer satisfaction from support for delivering and sending of product and service orders (Lee, 2001, 75). In summary we have the following hypothesis to investigate,

H3: e-satisfaction has a positive impact on e-loyalty in Pars Khodro CO.

\subsection{Reliability/ Fulfillment}

Fulfillment/reliability is explained as the delivery of the right product within the time frame promised with accurate product information displayed on the website so that customers receive what they expect to receive (Wolfinbarger \& Gilly, 2003). Therefore, we build the following hypothesis,

H4: Reliability/ Fulfillment have a positive impact on e-loyalty in Pars Khodro CO.

H5: Reliability/ Fulfillment have a positive impact on e-satisfaction in Pars Khodro CO.

\subsection{Website design}

Website design means the type of components must represent in explorer page and what attributions. In addition, it can be considered as design, develop, and maintain technical architecture of web-based functional programs (Brinck \& Gergle, 1998).

H6: website design has a positive impact on e-satisfaction in Pars Khodro CO.

\subsection{Responsiveness}

Responsiveness in our study is described as responsive, helpful, and willing service that responds to customer inquiries quickly (Wolfinbarger \& Gilly, 2003).

H7: responsiveness has a positive impact on e-satisfaction in Pars Khodro CO.

H8: responsiveness has a positive impact on e-confidence in Pars Khodro CO.

\subsection{Security/privacy}

Security/privacy includes security of credit card payments and privacy of shared information (Wolfinbarger \& Gilly, 2003). Initial research on e-commerce indicates that risk related to loss of consumers' privacy and security of personal information is an important barrier to consumers' Internet adoption and use (Hui et al., 2007).

H9: Security/privacy has a positive impact on e-confidence in Pars Khodro CO.

In previous years, there have been many studies performed on customer's loyalty. However, e-loyalty and framework for achieving it have not been considered, widely. In this paper, to create such framework, widespread study is performed in available and related resources. Table 1 demonstrates these major resources. Fig. 1 also shows relationship among different components of the proposed study of this paper. 


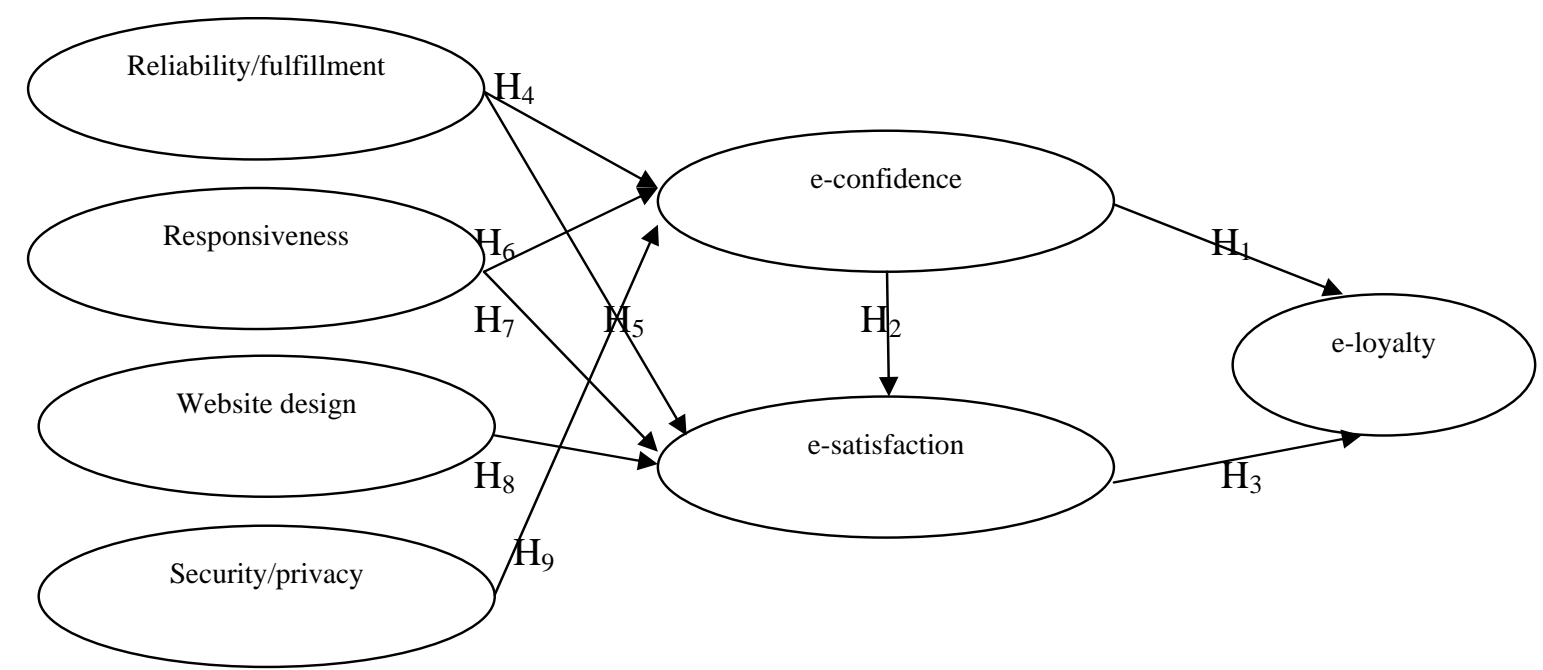

Fig. 1. conceptual model: e-loyalty development process.

Table 1

Research backgrounds

\begin{tabular}{|c|c|c|c|}
\hline No. & Researcher & Description & Results \\
\hline 1 & $\begin{array}{l}\text { Oliveira, } \\
2007\end{array}$ & $\begin{array}{l}\text { In this research, author attempted that } \\
\text { prove to exist relation between service } \\
\text { quality and e-loyalty focusing on } \\
\text { Zithambul's e-service quality. } \\
\text { Data is analyzed by SEM method. }\end{array}$ & $\begin{array}{l}\text { 1: quality of e-service impacts on e-loyalty. } \\
\text { 2: factors that influenced on e-service quality: } \\
\text { Information availability, ease use, privacy and } \\
\text { security, graphic surface, reliability, accountability. }\end{array}$ \\
\hline 2 & $\begin{array}{l}\text { Rolph \& } \\
\text { Srini, } 2003\end{array}$ & $\begin{array}{l}\text { Author surveyed factors influenced on } \\
\text { relationship between e-satisfaction and e- } \\
\text { loyalty. }\end{array}$ & $\begin{array}{l}\text { Factors that influenced on e-satisfaction and e- } \\
\text { loyalty: } \\
\text { Business level's mediators variables (confidence and } \\
\text { perceived value) } \\
\text { Individual level's mediators variables (comfort and } \\
\text { magnitude of purchase) }\end{array}$ \\
\hline 3 & $\begin{array}{l}\text { Jun \& Bin, } \\
2005\end{array}$ & $\begin{array}{l}\text { This survey is presented as a proposal to } \\
\text { China's communication industry. Data } \\
\text { analyzing is performed by Pearson's test }\end{array}$ & $\begin{array}{l}\text { Factors that influenced on loyalty: } \\
\text { Service quality, confidence, cost, employees' loyalty } \\
\text { and switching }\end{array}$ \\
\hline 4 & $\begin{array}{l}\text { Asim \& } \\
\text { hashmi, } \\
2005\end{array}$ & $\begin{array}{l}\text { A case study is performed in aviation } \\
\text { system website of Scandinavia and Norda } \\
\text { bank for achieving deep understands in } \\
\text { factors influenced on loyalty. }\end{array}$ & $\begin{array}{l}\text { Factors that influenced on e-loyalty: } \\
\text { Optimization, attributes, facilities, selection, } \\
\text { communication, protection, reciprocal relationship, } \\
\text { and development. }\end{array}$ \\
\hline 5 & $\begin{array}{l}\text { Clark, } \\
2007\end{array}$ & $\begin{array}{l}\text { Research model is conclude of sex factors } \\
\text { influenced on customer's loyalty by used } \\
\text { of "The Loyalty Guide" book. }\end{array}$ & $\begin{array}{l}\text { Factors that influenced on e-loyalty: } \\
\text { The most critical value received by customer, } \\
\text { geographical attributions, environment of goal } \\
\text { market, purchase share, and satisfaction. }\end{array}$ \\
\hline 6 & $\begin{array}{l}\text { Jungwon, } \\
\text { et al., } 2000\end{array}$ & $\begin{array}{l}\text { A multidimensional model of internet } \\
\text { shop customer's loyalty is created by web- } \\
\text { based survey of customers. Data } \\
\text { analyzing is performed by structured } \\
\text { analysis. }\end{array}$ & $\begin{array}{l}\text { 1: confidence and transaction cost are factors } \\
\text { influenced on customer loyalty. } \\
\text { 2: full information, common value, and relationship } \\
\text { are factors influenced on customer's confidence. } \\
\text { 3: transaction cost is influenced by number of rival, } \\
\text { uncertainty, and specialty of company. }\end{array}$ \\
\hline
\end{tabular}

The proposed model of this paper uses the following framework to examine different hypotheses. The primary objective is to find the important factors influencing on e-loyalty and how we can improve the e-business through increasing e-loyalty.

\section{Methodology}

Research population is series of customers that purchase pars Khodro's products in Tehran in 2011. Because population is unlimited, we have used the following sampling technique, 
$n=\left(\frac{Z_{\alpha / 2} \times \delta}{\varepsilon}\right)^{2}=\left(\frac{1.96 \times 0.667}{0.072}\right)^{2}=329.68 \sim 330$

The most important method for data gathering was to study related references and to distribute questionnaire in population. We have designed a questionnaire consists of seven categories including e-loyalty, e-satisfaction, e-confidence, website design, security/privacy, responsiveness and reliability/fulfillment. Cronbach alpha was calculated for all these items and they are well above the minimum desired level of 0.7 and Table 2 summarizes the results.

Table 2

Cronbach alpha

\begin{tabular}{llllllll}
\hline Variable & e-loyalty & e-satisfaction & e-confidence & Website design & Security/privacy & Responsiveness & Reliability \\
\hline Rank & 1 & 2 & 3 & 4 & 5 & 6 & 7 \\
Cronbach alpha & 0.938 & 0.927 & 0.933 & 0.820 & 0.742 & 0.956 & 0.736 \\
\hline
\end{tabular}

\section{Results}

As shown in Table 3, more than 80 percent of visitors were male. Other demographic data of population are shown in Table 3.

\section{Table 3}

Demographic data of population

\begin{tabular}{lll}
\hline & Number & Percent (\%) \\
\hline Sex & 271 & 82 \\
Male & 59 & 18 \\
\hline Age & & \\
$21-25$ & 48 & 15 \\
$26-30$ & 109 & 33 \\
$>30$ & 173 & 52 \\
\hline Education & & \\
Graduate & 48 & 9 \\
Undergraduate & 155 & 47 \\
Master & 106 & 32 \\
Ph.D & 41 & 12 \\
\hline Number of visit & & \\
$1-5$ & 139 & 45 \\
$6-10$ & 61 & 20 \\
$>11$ & 107 & 35 \\
\hline Time of visit (min) & & \\
$<30$ & 253 & 77 \\
\hline $30-60$ & 74 & 22 \\
\hline$>60$ & 3 & 1 \\
\hline
\end{tabular}

Table 4 shows the quality of seven variables of the questions in terms of either suitable or unsuitable.

Table 4

Quality of variables

\begin{tabular}{ll}
\hline Research variables & Quality \\
\hline Reliability/fulfillment & Suitable \\
Responsiveness & Unsuitable \\
Website design & Suitable \\
Security/privacy & Suitable \\
e-confidence & Suitable \\
e-satisfaction & Suitable \\
e-loyalty & Average \\
\hline
\end{tabular}


To make sure about the accuracy of measurement models of dependent and independent variables we have also used confirmatory factor analysis.

\subsection{Confirmatory factor analysis of research independent variables}

Fig. 2 shows the results of our analysis for different independent factors including web design (WEB1-WEB4), security (SEC1-SEC3), accountability (ACC1-ACC3) and fulfillment (FU1-FU2). As we can observe from the results, Chi-Square maintains a relatively high value and P-value is equal to 0.0000 , which means there are meaning relationship between different components of independent variables.

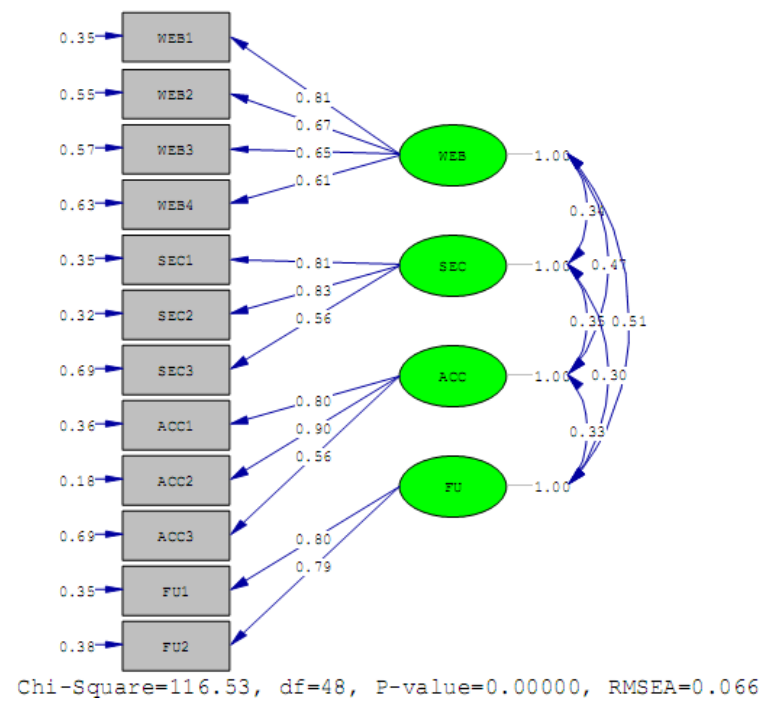

Fig. 2. The relationship between independent variables

\subsection{Confirmatory factor analysis of research dependent variables}

Fig. 3 shows the results of our analysis for different dependent factors including satisfaction (SAT1SAT9), trust (TRU1-TRU8) and e-loyalty (ELOY1-ELOY13). As we can observe from the results, Chi-Square maintains a relatively high value and P-value is equal to 0.055 . It seems the relationships are meaningful when the level of significance is set to $10 \%$.

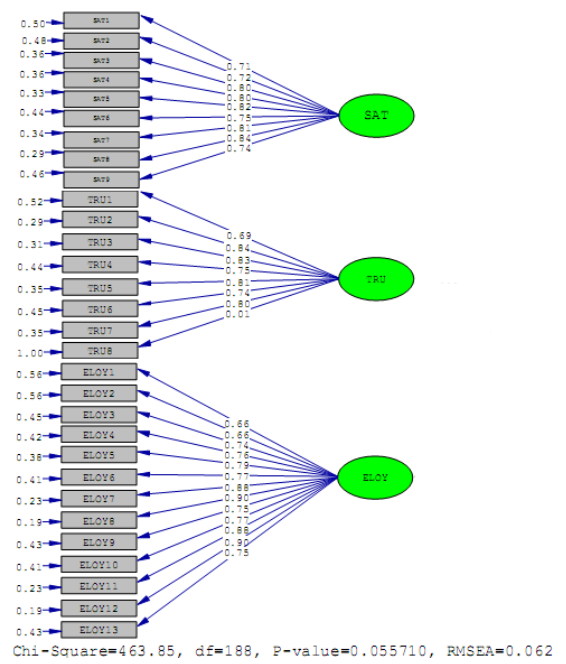

Fig. 3. The relationship between of dependent values 


\subsection{Test of research main hypotheses by path analysis}

The following structural model demonstrates relationships between independent variables such as fulfillment, website design, responsiveness, and between security and loyalty as well as between satisfaction and e-loyalty. Structural model demonstrates that there is a positive and significant relationship between all of variables except for responsiveness and e-confidence.

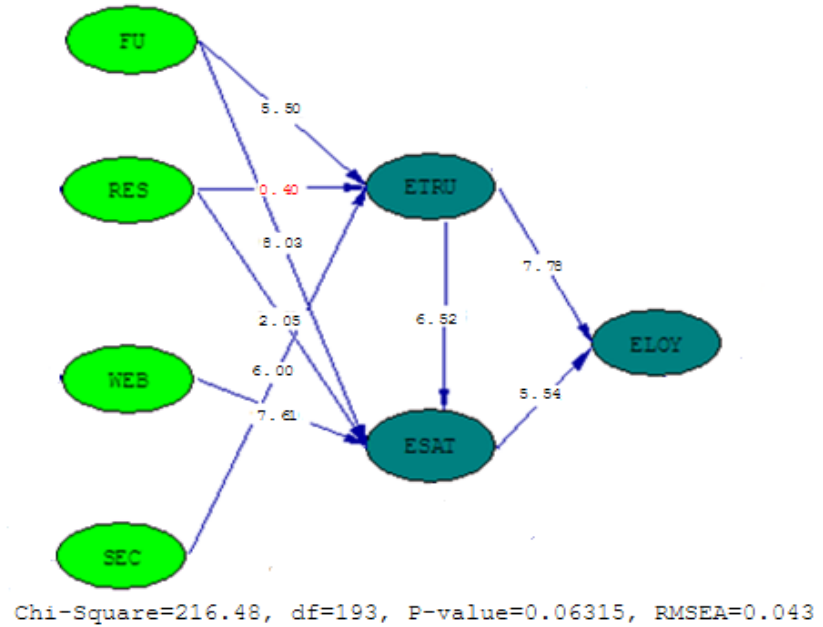

Fig.4. The values of the variables in the first stage

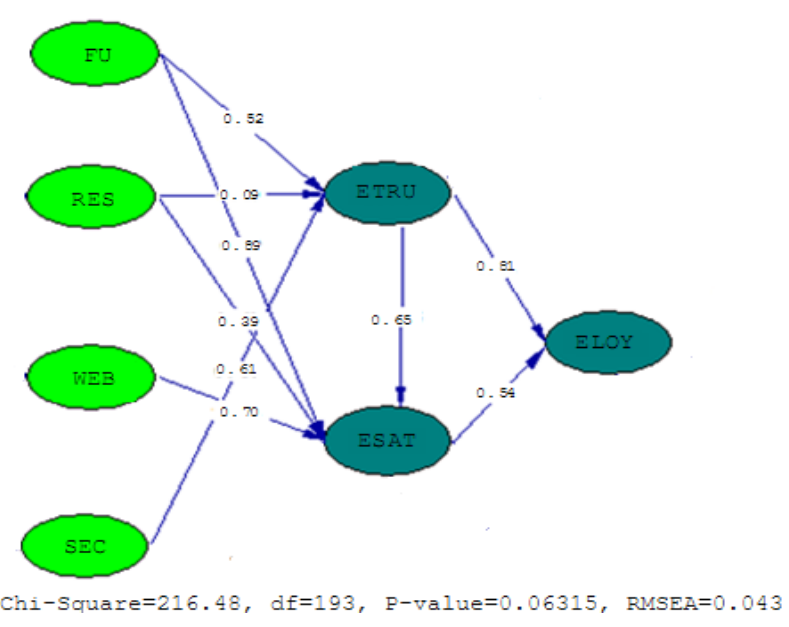

Fig. 5. The values of the variables in standard format

In addition, to test research hypotheses with use of structural equation, results show suitability of model goodness. Based on the observed data, it seems that there is a high-level conformity with conceptual model. GFI, AGFI, and NFI are 0.91, 0.9, and 0.92, respectively, which show relatively high goodness of fit of model. Table 5 shows details of our testing different hypotheses.

Table 5

Results of hypotheses test

\begin{tabular}{lc}
\hline Hypotheses & Test result \\
\hline H1: e-confidence has a positive impact on e-loyalty in Pars Khodro CO. & Accepted \\
H2: e-confidence has a positive impact on e-satisfaction in Pars Khodro CO. & Accepted \\
H3: e-satisfaction has a positive impact on e-loyalty in Pars Khodro CO. & Accepted \\
H4: Reliability/ Fulfillment has a positive impact on e-loyalty in Pars Khodro CO. & Accepted \\
H5: Reliability/ Fulfillment has a positive impact on e-satisfaction in Pars Khodro CO. & Accepted \\
H6: website design has a positive impact on e-satisfaction in Pars Khodro CO. & Accepted \\
H7: responsiveness has a positive impact on e-satisfaction in Pars Khodro CO. & Accepted \\
H8: responsiveness has a positive impact on e-confidence in Pars Khodro CO. & Rejected \\
H9: Security/privacy has a positive impact on e-confidence in Pars Khodro CO. & Accepted
\end{tabular}

As we can observe from the results of Table 5, expect one case, which is associated with the relationship between responsiveness and e-confidence, all other eight hypotheses have been confirmed. Therefore, we can conclude that e-confidence has a positive impact on e-loyalty and esatisfaction, e-satisfaction positively impacts on e-loyalty, reliability maintains positive impact on eloyalty and e-satisfaction. Website design and responsiveness both have positive impact on esatisfaction, security and privacy positively influence on e-confidence but there was no meaningful relationship between responsiveness and e-confidence at all. 


\section{Conclusion}

In this paper, we have presented an empirical study to measure the effects of seven factors on ebusiness in one of well-known auto makers in Iran. The results of our study have indicated that econfidence plays an important role on e-loyalty and e-satisfaction while e-satisfaction itself could impact positively on e-loyalty. In addition, reliability influenced positively on e-loyalty and esatisfaction, web-design and responsiveness affected e-satisfaction, security. Finally, the results of our study indicated that security and privacy could impact on e-confidence but we did not find any meaningful relationship between responsiveness and e-confidence. The moral story is that the management team must put more efforts on protecting buyer and seller's data security and they must increase security of their systems. A timely response could help customers increase their confidence while a fast delivery system plays an important role on customer satisfaction.

\section{References}

Asim, M., \& Hashmi, Y.(2005). E-Loyalty: Companies Secret Weapon on the Web. Master's Thesis, Lulea University of Technology.

Anderson, R. E., \& Srinivasan, S.S. (2003). E-satisfaction and e-loyalty: a contingency framework. Psychology \& Marketing, 20(2), 123-138.

Andreassen, T.W., \& Lindestad, B. (1998). Customer loyalty and complex services: the impact of corporate image on quality, customer satisfaction and loyalty for customers with varying degrees of service expertise. International Journal of Service Industry Management, 9(1), 7-23..

Bai, B., Law, R. \& Wen, I. (2008). The impact of website quality on customer satisfaction and purchase intentions: Evidence from Chinese online visitors. International Journal of Hospitality Management, 27, 391-402.

Bansal, H., MacDougal, G., Dikolli, S., \& Sedatole, K. (2004). Relating e-satisfaction to behavioral outcomes: an empirical study. Journal of Service Marketing, 18 (4), 290-302.

Brinck, T. Gergle, D., \& Wood, S. (1998). Website design from the trenches. Tutorial at CHI 98 Human Factors in Computing Systems, Los Angeles.

Bolton, R. N., \& Drew, J.H. (1991). Linking Customer Satisfaction To Service Operations and Outcomes, Service Quality: New Directions in Theory and Practice, 1994, Chapter 8, Newbury Park, CA: Sage Publications, Inc., 173-200

Buttle, F., \& Burton, J. (2002). Does service failure influence customer loyalty?. Journal of Consumer Behavior, 1(3), 217-27.

Corbitt, B.J., Thanasankit, T., \& Yi, H. (2003). Trust and e-commerce: an study of consumer perceptions. Electronic Commerce Research and Applications. 22, 203-215.

Clark, P. (2007). The six key factors that influence customer loyalty. 98-105.

Dick, A. \& Basu, K. (1994). Customer loyalty: an integrated conceptual framework. Journal of Academy of Marketing Science, 22, 99-113.

Dodds, W.B., Monroe, K.B., \& Grewal, D. (1991). Effects of price, brand, and store information on buyer’s product evaluations. Journal of Marketing Research, 28(3), 307-319.

Donio, J., Massari P., \& Passiante, G. (2006). Customer satisfaction and loyalty in a digital environment: an empirical test. Journal of Consumer Marketing, 23(7), 445-457.

Eppie, Y. (2007). Factors Affecting Customer Retention in Internet Banking among Hong Kong Professionals and Business Practitioners. Doctoral Dissertation. Newcastle: University of Newcastle.

Flavian, C., Guinaliu, M., \& Gurrea, R. (2006). The role played by perceived usability, satisfaction and consumer trust on website loyalty. Information \& Management, 43(1), 1-14.

Fornell, C. \& Wernerfelt, B. (1987). Defensive marketing strategy by customer compliant management. Journal of Marketing Research, 24, 337-346.

Ganesh, J., Arnold, M. J. \& Reynolds, K. E. (2000). Understanding the customer base of service providers: An Examination of the differences between switchers and stayers. Journal of Marketing, 64(3), 65-87. 
Gazor, H., Nemati, N., Ehsani, A., \& Nazari Ameleh, K. (2012). Analyzing effects of service encounter quality on customer satisfaction in banking industry. Management Science Letters, 2(3), 859-868.

Gefen, D., \& Straub, D.W. (2004). Consumer trust in B2C e-Commerce and the importance of social presence: experiments in e-Products and e-Services. The International Journal of Management Science, 32, 407-424..

Gefen, D. (2002). Reflections on the dimensions of trust and trustworthiness among online consumers. ACM Special Interest Group on Management Information System, 33, 38-53.

Goodwin, C. (1991). Privacy: Recognition of a consumer right. Journal of Public Policy \& Marketing, 10, 149-166.

Gummerus, J., Liljander, V., Pura, M. \& Van Reil, A. (2004). Customer loyalty to content-based websites: the case of an online health-care service. Journal of Service Marketing, 18(3), 175-186.

Guptaa, A., Bo-chiuan, S., Zhiping, W. (2004) Risk profile and consumer shopping behavior in electronic and traditional channels. Decision Support Systems, 38, 347-367

Gommans, M., Krish, S. K., \& Katrin, B. S. (2001). From brand loyalty to eloyalty: A conceptual framework. Journal of Economic and Social Research, 3(1), 43-58

Lee, G.G., \& Lin, H.F. ( 2005). Impact of organizational learning and knowledge management factors on e-business adoption. Management Decision, 43(2), 171-188.

Gustafsson, A., Johnson, M., \& Roos, I. (2005). The effects of consumer satisfaction, relationship commitment dimensions, and triggers on consumer retention. Journal of Marketing, 69(4), 210-8.

Hui, K-L., Teo, H.H., \& Lee, S-Y.T. (2007). The value of privacy assurance: an exploratory field experiment. MIS Quarterly, 31 (1), 19-33.

Hallowell, R. (1996). The relationships of customer satisfaction, customer loyalty, and profitability: an empirical study. International Journal of Service Industry Management, 7(4), 27-42.

Harris, L., \& Goode, M. (2004). The four levels of loyalty and the pivotal role of trust: a study of online service dynamics. Journal of Retailing 80, 139-158.

Hoffman, D.L., Novak, T.P., \& Peltra, M. (1999). Building customer trust online. Communications of the ACM, 42(4), 80-85.

Jun, X., \& Bin, L. (2005). An empirical study of customer loyalty of the telecommunication industry in China. Communications of the ACM, 15-17.

Javalgi, R.G., Radulovich, L.P., Pendleton, G., \& Scherer, R.F. (2005). Sustainable competitive advantage of internet firms: a strategic framework and implications for global marketers. International Marketing Review, 22(6), 658-672.

Jungwon, L., Jinwoo, K., \& Jae, Y. M. (2000). What makes internet users visit cyber stores again? Key design factors for customer loyalty. Communications of the ACM, 1-58.

Jiang, P. \& Rosenbloom, B. (2004). Customer intention to return online: price perception, attributelevel performance, and satisfaction unfolding over time. European Journal of Marketing, 39(1/2), 150-174.

Kim, E.(2003). Factors impacting customers trust in E-business: An empirical study of customers initial trust in E-business. A Dissertation for the Doctor of Philosophy Degree. Southern Illionois University.

Kim, J., Jin, B. \& Swinney, J. (2009). The role of etail quality, e-satisfaction and e-trust in online loyalty development process. Journal of Retailing and Consumer services, 16(5), 1-9.

Lee, M.K.O., \& Turban, E. (2001). A trust model for consumer internet shopping. International Journal of Electronic Commerce, 6(1), 75-91.

Lee, G. \& Lin, H. (2005). Customer perceptions of e-service quality in online shopping. International Journal of Retail and Distribution Management, 33(2), 161-176.

Montoya-Weiss, M.M., Voss, G.B., \& Grewal, D. (2003). Determinants of online channel use and overall satisfaction with a relational, multichannel service provider. Academy of Marketing Science, 31(4), 448-458. 
McNeal, R.B.Jr. (1999). Parental involvement as social capital: Differential effectiveness on science achievement, truancy, and dropping out. Social Forces, 78, 117-144.

Morgan, R.M., \& Hunt, S.D. (1994). The commitment-trust theory of relationship marketing. Journal of Marketing, 58, 20-38.

Hill, N. \& Alexander, J. (2000). Handbook of Customer Satisfaction and Loyalty Measure. Gower Publishing Company.

Nemati, B., Gazor, H., MirAshrafi, S. N., Nazari Amele, K. (2012), Analyzing E-service quality in service-based website by E-SERVQUAL, Management Science Letters, 2(2), 727-734.

Oliver, R. L. (1999). Whence consumer loyalty? Journal of Marketing, 63, 33-44.

Parasuraman, A., Zeithaml, V.A., \& Malhotra, A. (2005). E-S-QUAL: a multiple-item scale for assessing electronic service quality. Journal of Service Research, 7(3), 213-33.

Park, C-H., \& Kim, Y-G. (2003). Identifying key factors affecting consumer purchase behavior in an online shopping context. International Journal of Retail and Distribution Management, 31(1), 1629.

Rolph, E. A., \& Srini, S. S. (2003). E-Satisfaction and E-Loyalty: A contingency framework. Psychology \& Marketing, 20(2), 123-138

de Oliveira, R. C. (2007). Evidences from link between quality and loyalty in eservice: an empirical study. Revista Eletrônica Sistemas \& Gestão, 2 (1), 1-15.

Reichheld, F.F. \& Sasser, E.W. (1990). Zero defections: quality comes to services. Harvard Business Review, 14, 495-507.

Rust, R.T. \& Zahorik, A.J. (1993). Customer satisfaction, customer retention and market share. Journal of Retailing, 69(2), 193-215.

Sarv, D., Ming, F., Rajiv, K. (2003). E-Loyalty-Elusive Ideal or Competitive Edge?. Communications of The ACM, 46(9), 184-191

Sirdeshmukh, D., Singh, J., Sabol, B. (2002). Consumer trust, value, and loyalty in relational exchanges. Journal of Marketing, 66(1), 15-37.

Shanker, V., Smith, A.K. \& Rangaswamy, A. (2003). Customer satisfaction and loyalty in online and offline environments. International Journal of Research in Marketing, 20, 153-175.

Segares, A.H. (1997). Assessing the unidimensionality of measurement: A paradigm and illustration within the context of information system research. Omega, 25, 107-121.

Srinivasan, S.S., Anderson, R., \& Ponnavolu, K. (2002). Customer loyalty in e-commerce: an exploration of its antecedents and consequences. Journal of Retailing, 78(1), 41-50.

Van Riel, A., Liljander, V., \& Jurriens, P. (2001). Exploring consumer evaluations of e-services: a portal site. International Journal of Service Industry Management, 12(3/4). 359-377.

Verhoef, P.C., Francis, P.H., \& Hoekstra, J.C. (2002). The effect of relational constructs on customer referrals and number of services purchased from multiservice provider: does age of relationship. Journal of the Academy of Marketing Science, 30(3), 202-216.

Wolfinberger, M. \& Gilly, M.C. (2003). e-TailQ: dimensionalizing, measuring and predicting etail quality. Journal of Retailing, 79, 183-198. .

Yang, X., Ahmed, Z., Morry, G., Boon, G., Mei, T., \& Hwa, L. (2003). Consumer Preferences for commercial Web site design: an Asia-Pacific perspective. Journal of Consumer Marketing, 20, 10-27.

Yazdanpanah, A.A., \& Gazor, H. (2012). Detecting success factors of electronic customer relationship management (e_CRM) system to establish an appropriate model in police call Centre of Iran, Management Science Letters, 2(1), 339-350.

Yang, Z., \& Peterson, R.T. (2004)' Customer perceived value, satisfaction, and loyalty: The role of switching costs. Psychology \& Marketing, 21(10), 799-822. 